\title{
"On the edge of Siberia...": Russian Old Timers in Some Twentieth and Twenty-First Centuries Writings
}

\author{
Julia G. Khazankovich \\ M. K. Ammosov North-Eastern Federal University, Bld. 42, Kulakovsky St., Yakutsk, 6770oo, Russia. \\ Email: hazankovich33@mail.ru
}

Received February 21, 2017; Revised April 17, 2017; Accepted April 20, 2017; Published May 7, 2017.

\begin{abstract}
Autochthonous world of the Arctic aboriginal peoples is traditionally associated with the indigenous smallnumbered peoples of the North - Yukaghirs, Chukchis, Evenks, and other ethnic groups including Russian old-timers (russkoustintsy and pokhodchane). Though being Russian in terms of language and ethnic identity, they are legally incorporated in Yakutia to the same category for being culturally close to the traditional cultures of the indigenous peoples of the North. The relevance of invoking this theme is due to the need for non-ideological interpretation of the problem concerned "Russian world", which is a cultural and historical concept of the community that is engaged by its adherence to Russia, as well as to the Russian language and culture. Studying the essays by Valentin Rasputin, in particular, his essay "Russkoye Ustye", as well as the book "Next to the Ice on the Edge of Oecumena: Russkoye Ustye. Return to Roots", whose compiling editor is an old-timer, Russians' descendant Igor Chikachyov, enables us to analyse the topic from the perspective of hermeneutic approach. Identifying the historical and aesthetic context of the essay by V. Rasputin and the book of Igor Chikachev about the culture of Russian old-timers of the Arctic allows drawing conclusion that their content was inspired by the search, the acquisition, and the postulation of existential foundations of Russian national mentality. Rasputin's interest towards the culture of Russkoye Ustye, his meeting with the Russian old-timer Alexey Chikachyov allowed the writer to include in the essay his own ideological codes; to turn spatial and temporal realities into aesthetic coordinates (river, the Indigirka, the village of Russkyoe Ustye, tundra-sendukha).
\end{abstract}

Keywords: Arctic, Yakutia, Siberia, Russian old-timers, V. Rasputin, Chikachyov, essay, the indigenous small-numbered peoples of the North.

\section{Introduction}

According to the American archives, the first Russian settlers came to the delta of the Indigirka River, the northernmost part of Siberia, in the late XVIth century. They fled from Ivan the Terrible's oprichnina and came to these remote places not by land, but rather by water, arriving in 14 karbases and kochs, which are large boats. They created a kind of "small Arctic civilization of the Russian people" in the Arctic (I. Chikachyov), which has its own culture and its own language, the language spoken in Novgorod in the XVth and XVIth centuries.

For Rasputin, Yakutia is associated with the village of Russkoye Ustye and its first settlers - "doselnie people", who were descendants of the Viatichi (inhabitants of Vyatka), Novgorodians and Ustiuzhani (inhabitants of Ustyug) of the XVIth century, in contrast to "Cossacks", "peasants" and "Verkhovsky" (arrived from the Indigirka riverhead), who settled later. Yakutia became a place where the writer could experience the authentic culture of the Russian old-timers. The village of Russkoye Ustye represents a special locus for the soil-bound (pochvennik) writer. Russkoye Ustye is not the edge of the land, but rather the place of exile and penal servitude. On

(c) AesthetixMS 2016. This Open Access article is published under a Creative Commons Attribution Non-Commercial 4.0 International License (http://creativecommons.org/licenses/by-nc/4.o/), which permits non-commercial re-use, distribution, and reproduction in any medium, provided the original work is properly cited. For citation use the DOI. For commercial re-use, please contact editor@rupkatha.com. 
the one hand, it is a concrete historical space, on the other hand, it is full of mysteries, miracles and secrets. The small village on the edge of Siberia became a discovery for Rasputin as well as the missing link in his study of the "Russian idea" and the historical paths of Russia, on which the writer continued to meditate in his last book "Those twenty deadly years". "There is no Russia without the village. The latter represents our roots - cultural, spiritual, economic, state, as well as the people's mentality. The village is the source of common sense [1, p.182].

Rasputin felt this common sense in the lower Indigirka, in the village of Russkoye Ustye, visiting it in 1985. Alexey Chikachyov wrote in his memoirs: "From our first meeting I felt some affinity and closeness in him; both of us felt involuntarily attached to each other. Both of us had cold and bitter childhood, both are like-minded Russian patriots. He made me shape up my scattered notes on Russkoye Ustye history." [2]. Chikachyov told about the gratitude towards Rasputin felt by the residents of Russkoye Ustye, because he, with deep understanding and sympathy, saw in Russkoye Ustye the remnants of native being, which had been the basis of all Russian life in the past.

\section{Methodology}

Hermeneutic approach allows plunging into ethnic and aesthetic context of cultural realities, expressed in the essay not about "the other culture" of Russkoye Ustye, but rather on authors' coliving with its residents - Russian old-timers.

\section{Literary comprehension}

Rasputin shows his worth as an artist in the essay "Russkoye Ustye": he neither invents nor makes up, but rather studies the object: the merged voices of Rasputin-writer [see: 3], [4], [5], [6] and Rasputin-publicist give the quality of prophecy to the text [7, p.10]: "Norm is a norm, it moderates colours, sounds and all other things". A single style of life is the same as a single battlefront (obsolete word, meaning "stand at attention", "spring at attention"), in which everyone must fall in to maintain a straight line. It is favourable for the style, but it impoverishes life [8, p.3]. This issue of a common mode of life mentioned by the writer and the one, which caused his concern in the late 1980s, has again become topical nowadays.

The essay "Russkoye Ustye" is of artistic and publicistic nature; author's stance is especially significant in it: Valentin Rasputin's voice is distinctly heard in it; one can understand his opinion on events, his estimations, response, likes and dislikes as a result of perception and deep understanding of the situation. "But why Indigirka? Was not it possible, passing river after river, to choose land which is less severe and more favourable for life even in the Far North? Remote is remote, if that is where they saw salvation, but even if they sought remoteness they would not have gone too far without heavy incentive, and at the same time this was precisely going too far", for none had as yet beaten any paths farther east. What actually drew the Russians to that particular place? What did they find there that could even partially make up for the homeland they had left behind? Having brought along the biblical tales of the creation of the world, the Russians of Russkoye Ustye lost no time expanding on them to include the tundra as well. Their legends about the origin of the sendukha and its inhabitants, about the appearance of nearby ghosts and spirits, of sins and vices in human beings themselves...These legends, true stories and tales contain so much harmony, learning and soul [8, p. 5-6, 14]. 
In what terms can one determine the live style of Rasputin as an essay-author? One may find an answer in A.G. Chikachyov's memoirs: "The gifted artist had the astonishing capacity to instantly grasp your thoughts, mood and feelings." While writing the essay "Russkoye Ustye" Valentin Grigorievich wrote letters to me (Chikachev, noted by the author) with requests to clarify some words and word expressions from Russkoye Ustye residents' vocabulary. In general, I understood that V. Rasputin is deliberate, thoughtful and even meticulous writer..." [2]. Rasputin makes a focus on history and life of ancient settlement of old time people, transforming his meeting with Russkoye Ustye into aethetic object-event: "I heard about Russkoye Ustye too late, If I'd known about it, say, ten years earlir, I could then have managed to capture a lot of the things what now remain only in memory while they were still alive and functioning...I came upon Russkoye Ustye at what I belive was the exact crossing point when the old days were becoming echoes of the old days, at the very moment when villagers were bidding them farewell forever. And the universal mad rush has also penetrated those parts...At last, I heard the language...Lord, what a joyous messenger, what pleasure and good fortune (in the words and sounds by which it has come down to us in the present) the Russian language in Russkoye Ustye [8, p.3-4.].

In Rasputin's essay, the historic fact of coming by sea and subsequent Russians' adaptation at Indigirka region between the sixteenth and twentieth centuries, is turned into event and became the basis for the character and the plot. The publicist-artist' stance manifests itself in multifaceted speech and composition structure of the essay itself, which consists of publicistic deliberations, Rasputin's pictures-reflections, Russkoye Ustye residents' memoirs, who keep in their memory "prilogi", i.e. legends and tales. But above all Rasputin is interested in the human being, his spiritual core. In Rasputin's work we find the description of spiritual type of "old time people" - social and cultural phenomenon similar to Siberian people. Russian old-timers have not succumbed to influence by Yakut, Yukaghirs, Evenks, Chukchis, Evens people who surrounded them. The Russian old-timer took only the most essential hunting, fishing and household terms from the local languages. The self-contained old way of life, isolation of language and customs, the striking retentiveness of memory with respect to folklore and traditions helped the Russian old-timers to preserve themselves in this land.

The phenomenon of "old time" people would not exist without aboriginal peoples of Indigirka tundra: "But first, he had to look around and figure out how to survive and with whom to be a neighbour. Yakuts back then had not yet descended to the lower Indigirka ... The place where Russians settled appeared to be the closest to the one where Yukaghirs lived; the latter were freely brought up under the mighty tundra sky into unselfish, gentle, and tidy people ...” [8, p.7].

But the very topos of tundra formed the soul of the Russian old-timer. "Few people in the Arctic call the tundra tundra. They call it the sendukha ... Tundra designates geography and pedigree; sendukha is nature's primordial power, all-encompassing and almighty, which punishes and rewards, 'Mother Sendukha, at whose breast we are fed!' they all exclaim, praying and giving thanks to it each in his own language" [8, p.11-12]. The tundra is impossible to easily measure, study and adjust in the usual sense; the sendukha succumbs to nobody; Sendukha is topos which exists beyond time and space, it is saturated with signs of spontaneity both in the culture of Russian old-timers and in Valentin Rasputin' perception. For Rasputin the locus of Russian oldtimers in the lower Indigirka is not the object space, but rather some metaphysical topos [11, p. 87], a kind of symbol of unification of diverse, multi-language and multicultural Russia: "The former Russians along the Kolyma called themselves Kolymans and those along the Indigirka a hundred versts south of Russkoye Ustye became Indigirkans, realising that they were neither 
Russians nor Yakuts but something in between, that they'd been ground to a uniform consistency and mixed together, and that they belonged to a locality but not to a particular ethnic group..." [8, p. 8].

\section{Reflection of the "Russian world" of the Arctic in ethnographic publicism}

In 2015 the book "Next to the Ice on the Edge of Oecumena: Russkoye Ustye. Return to Roots" was published. Igor Chikachyov, representative of modern Russian old-timers, became the compiling editor of the book [9]. In Russkoye Ustye the embellishment "intricate Rus" remained; archive photographs and V. Zenzinov's materials as well as sounds of the living Russian Word express this irregularity in the book. The book includes historical vocal and choreographic pictures "On the Edge of Oecumena" by Alexei Chikachyov, the play "Distant Mother" by Igor Chikachyov based on V. Zenzinov's and A. Chikachyov's work, Julia Kuzmichyova's article on the language and folklore of Russkoye Ustye residents, the story of the "Exile into Russian Siberia" by Vladimir Zenzinov; noted by G. Berestov "doselnye" (old time) Russian songs, stories of Russkoye Ustye, papers on local history, data from unfinished catalogue on borrowed words in the dialect of Russkoye Ustye, which gives a complete picture of the archaic and figurative language of old time Indigirka people. The book also includes notes of outstanding linguist Maria Druzhinina, harmoniously written in to the collection of articles.

All presented materials give the reader deep understanding of everyday life and culture of Russians on the Indigirka, which were not "colonists" in the conventional sense.

The main contents of the book are preceded by the poetic foreword written by Vladimir Chlenov, which ends with the words: "...such books in concentrated form bring to the Russian reader historical and spiritual outbursts, all that unites us under a term such as Russia. Way to go!".

Russkoye Ustye dweller is a person of special spiritual constitution as well as of special character, formed by "sendukha" (tundra), fortified by ice and brought up by particular practice of relations and by the co-existence with the natives of the Allaikha River - Yukaghirs and Evens: "Here they found the promised land, here became relatives with local tribes, here they live preserving their relict language and ancestors' customs for many centuries. There were few women among settlers, therefore they chose wives from friendly Yukaghir tribes. These women along with Russian sisters became preservers of the hearth, through whom traditions, culture and kind attitude towards neighbours were passed. Russkoye Ustye dwellers never had conflicts with neighbours; there has long been the custom in their society, which mothers cultivated in their children. The Russian old-timers' testament was the following statement: You may quarrel and even fight with each other, but never offend Ukagirs, as they are kind people [9, p. 211].

Zenzinov V.M., being in the Russkoye Ustye for the first time (in deportation), was amazed to see "genuine Russia". He writes about the amazing national constancy of Russkoyeustyens (inhabitants of Russkoye Ustye), who not only did not succumb to other ethnic influences, but conquered Yakuts and Yukaghirs to their influence, forcing them to speak Russian, follow Russian customs, and wear Russian clothes. However, Zenzinov noted certain other ethnic elements in the culture and life of Russkoustyans; his descriptions are quite different from the observations of other researchers: "Taking, as all Slavs, rites of Christianity, they [Russkoustintsy note of the author] have saved the soul of the heathen" [quote by: 13, p. 50], i.e., most likely, by this phrase we should understand that the heathendom of Russkoyeustyens is not acquired 
through contact with the aborigines, but swiped from deeply hidden pre-Christian Slavic heathendom, which came out in isolation and alien surrounding.

Besides Russkoye Ustye, Russkoustyan group occupied numerous villages, the vast majority of which were abandoned in the XXth century, and today some of them are used in summer as hunting-fishing areas. In fact, Russkoye Ustye is not a separate specific settlement, but a collection of small villages located in the delta of the Indigirka River.

According to the researchers, atypical Slavic appearance that was quite common among Russkoyeustyens (highly likely, as a consequence of mixed marriages first of all with Yukaghirs at an early stage of development of the territory) has never prevented the authorities from counting Russkoyeustyens as Russians. Although, many todays Russkoyeustyens are characterized by pronounced Mongoloid facial features. At that, they claim themselves that, first and foremost, their roots are associated with Yukaghirs.

We cannot say confidently, what prompted the authorities to classify Russkoyeustyens as Russians rather than Yukaghirs, for example. However, it is quite reasonable to assume that this reckoning occurred primarily due to the fact that they spoke the Russian language and still professed the Orthodox faith. Besides, a considerable role was played by what is called the "everyday practices".

The vast majority of researchers, who were in different times in Russkoye Ustye, portrayed local residents solely as the Russians. At that, all of them have consistently expressed enthusiasm regarding specific characteristics of the local Russian culture, everyday customs, folklore, as well as dialect and language differences, which still remained in Russkoye Ustye, but were lost long ago in the European part of Russia.

However, the local community, which was considered to be Russian, in the XXth century separated themselves from all other Russian newcomers, calling them "entrants" [12, p. 22-23], and maintained good-neighborly relations with foreigners (Russkoyeustyens considered the Yukaghirs, Evens and Evenks as foreigners, though not the Yakuts and Chukchis): "About Lamuts and Yukaghirs [Russkoustyans] used to say: "These people are diligent," "If we are hungry, they will bring the meat of deer and all that they have without requesting". They assure that they themselves treat the reindeer herders as "the native father"; "We will stock up them fish, tea, tobacco"; "We do not smoke ourselves, we will leave it to Lamut" [12, p. 23]. At that, they pronounced Russian words with their specific accent (noted by the author).

Birkenhof A.L. believes such attitude to be quite sincere, however, admits that there are some echoes of those times (XVIIIth century), when, going round his district, an official ("the commissar") checked, among other things, the execution of the order of Irkutsk vicegerency about the attitude to the local "frivolous people": "By no means those peoples should not be grieved and should be treated with gentleness in accordance with the Apostolic preaching". Supposedly, similar orders defending the "frivolous peoples" from the arbitrary actions are known for the XVIIth century [12, p. 23].

For us, in this case it is important to note the fact that the aforementioned orders of the authorities, which were addressed primarily to departmental and service people, and more broadly - to all Russians, were taken by Russkoyeustyens personally, i.e. at that time Russkoyeustyens considered themselves Russians. Until the middle of XXth century, among Russkoyeustyens there was the custom to take children for "upbringing" from those Yukaghir and Even multi-child families, with whom they maintained partnerships. At that, the child adopted 
into the family was not in the same position as native children: in fact, he was a gratuitous worker.

The early 1930 s were marked by the beginning of qualitatively new stage in the life of Russkoyeustyens. In 1931, the first collective farms were organized in the region, and all former commoners simultaneously turned into members of a collective farm. But, as elsewhere in the Soviet Union, a new life in collective farm made no obvious changes in daily round of indigenous population, except of replacing the self-regulating economic activity by an organized muddle, a range of meaningless prohibitions and restrictions, as well as exorbitant fees in favour of the state [13, p. 32]. Another consequence of collectivization was the so-called consolidation of settlements, i.e. the concentration of the local population in several villages. Also in 1931 a school was built in Russkoye Ustye that was marked by the beginning of the struggle against religion. This led to the fact that a farm club was opened in the building of the Orthodox temple, and whole iconostasis was ordered to be drown in the waters of Indigirka. "New life" was built under the governance of the immediately created "Communist cell" under the close supervision of law enforcement authorities.

As for the "Russianness", it was confirmed at the official level: in all documents Russkoyeustyens appeared as Russians. However, this caused disagreement of the "entrants", who surged into the region later, especially in the 1950s. Of course, they were unable to abolish the official classification, but at the mundane level did everything in their power to separate themselves from the strange "Russians" with pronounced Mongoloid features and dark skin, who, from their viewpoint, could not even speak the Russian language. It was exactly this time when informal but widespread term "local Russians" (or simply "locals" in oral speech), which appeared as early as in 1930-1940s, became used commonly. This was not registered in the passports, but has penetrated even into such a serious document as farmer's employment book, not to mention the less important documents, like medical records, etc. [13, p. 38].

In the post-perestroika years of 1990s, classes in authentic language of Russian old-timers were abolished in Russkoye Ustye. Now the language is taught again. It happened after the interference of Vladimir Tolstoy, a Leo Tolstoy' descendant and dedicated guardian of Yasnaya Polyana, who visited Russkoye Ustye (the oecumene of the Russian culture) in 2013. It is noteworthy, that he got interested in the culture of Russian old-timers after reading the essays "Down the Lena River" and "Russkoye Ustye" by Valentin Rasputin. So, in tundra beyond the polar circle, people are now trying to save the preserved old Russian language of Ivan the Terrible period, which is represented by two dialects - Russkoustinsky and Pokhodsky, each of which has its own special intonation system, stress, idyosyncratic lisping, and common for both of them archaism and figurativeness. The book also includes data from "Dialect Dictionary of Russkoye Ustye" by Alexei Chikachyov in which we find lost by the modern Russian language meanings of familiar words: For instance, the word zhalet (to feel sorry for somebody) is used in the meaning to love (On svoikh sester shibko sil'no zhaleet - He feels sorry for/loves his sisters very much). According to V.Rasputin, "Russian old-timers' speech reminds of either remote sound of the wind, or lisp of grass and stipa; something natural resembling the voice of nature" [10, p.21].

\section{Conclusion}

The article shows the relevance of non-ideological interpretation of the issue concerning "Russian world" through appeals to artistic essays of Valentin Rasputin ("Russkoye Ustye"), as well as documentary collection "Next to the Ice on the Edge of Oecumena: Russkoye Ustye. Return to 
Roots". The methodology of the hermeneutical approach provided the opportunity to steep in the ethnic and aesthetic context of the cultural realities of Russian old-timers of the Far North.

Artistic and publicistic essay "Russkoye Ustye" shows the attitude of Valentin Rasputin in relation to the "Russian North", the author's view on events, evaluations, likes and dislikes in relation to spiritual type of "doselnie people" - a sociocultural phenomenon that has not succumbed to the influence of the surrounding aborigines, who have learned only hunting, fishery and other household requirements, have kept a closed old style being, the isolation of language and culture, folklore and traditions.

A unique confirmation to the observations of Rasputin is the book "Next to the Ice on the Edge of Oecumena: Russkoye Ustye. Return to Roots", containing a wealth of ethnographic material about the life and culture of the Russians living at Indigirka.

Interpretation of the essay about Russkoye Ustye, proposed by the author, is a pillar for further comprehension of the national world view, soul, and culture of Russian old-timers living on the edge of Siberia at the coast of the Arctic Ocean.

\section{References}

1. Rasputin, V.G., 2012. EHti dvadcat' ubijstvennyh let: besedy s Viktorom Kozhemyako [Those twenty deadly years: a conversation with Viktor Kozhemyako] [Text]. Moscow, Eksmo, 317 p.

2. Chikachev, I., 2015. Pomyanem Valentina Grigor'evicha dobrym slovom [Recollect Valentin Grigoryevich with a kind word] [Text]. Retrieved 25/05/2015 from www.1sn.ru/132958.РАСПУТИН.

3. Clark, K., 1982. Zhdanovist Fiction and Village Prose. Russian Literature and Criticism. Ed. E. Bristol. Berkeley, pp. 36-48.

4. Dunlop, J., 1983. The faces of contemporary Russian nationalism. Princeton, Priceton University Press, $363 \mathrm{p}$.

5. Brown, D.B., 1993. The last years of soviet Russia literature: Prose fiction, 1975 -1991. Cambridge, Cambridge University Press, 208 p.

6. Kathleen, F. and Parthé, 1992 Russian village prose: the Radiant Past. Princeton: Princeton University Press, pp. 216.

7. Prokhorov, G.S., 2013. Poehtika hudozhestvenno-publicisticheskogo edinstva (na materiale literatury perioda klassicheskogo posttradicionalizma) [The poetics of artistic and journalistic unity (based on the literature of the period of classical post-traditionalism)] [Text]. Higher doctorate thesis, Moscow, Publishing House of Russian State Humanitarian University, 34 p.

8. Rasputin, V.G., 1988, Russkoe Ust'e [Russkoye Ustye] [Text]. Polyarnaya Zvezda, 3, pp. 3-19.

9. U l'dov na krayu Ojkumeny. Russkoe Ust'e. Vozvrashchenie k istokam. [Next to the Ice on the Edge of Oecumena: Russkoye Ustye. Return to Roots] [Text]. Yakutsk, Literary Fund. 2015, 278 p.

10. Beseda o "Slovo o polku Igoreve" akademika D.S.Lihacheva i pisatelya V.G.Rasputina [Talk about "The word about Igor's regiment" of the Academician D.S. Likhachev and writer V.G. Rasputin] [Text]. Ogonek, 1986, 12, pp. 12.

11. Zhelobtsova, S.F., Khazankovich, Yu.G., and Zhelobtsov, F.F., 2016. YAkutskaya tema v russkoj literature HKH veka [Yakut theme in Russian literature of the XXth century] [Text]. Bulletin of M.K. Amosov North-Eastern Federal University, 4(54), pp. 78-89. 
12. Birkenhof, A.L., 1972. Potomki zemleprohodcev. [Descendants of path-breakers] [Text]. Memories and essays. Moscow, Mysl', $121 \mathrm{p}$.

13. Golovko E., Shvaitser, P., and Vakhtin N., 2004. Russkie starozhily Sibiri: Social'nye i simvolicheskie aspekty samosoznaniya [Russian old-timers of Siberia: Social and symbolic aspects of identity] [Text]. Moscow: Novoe Izdatelstvo. 